\title{
A Journey from the Shipwreck to the Salvage in Nadine Gordimer's Selected Short Stories
}

\author{
Sangita T. Ghodake \\ P D E A.’s Prof. Ramkridhna More Arts, Commerce and Science College, Akurdi, Pune, Maharashtra, India \\ *Corresponding Author: sangita.ghodake@gmail.com
}

Copyright $(\underset{0}{ } 2014$ Horizon Research Publishing All rights reserved.

\begin{abstract}
Nadine Gordimer's Jump and Other Stories (1991) is a collection of sixteen stories that can be best described as microcosm of the life in Africa. Being a humanist her prominent concern lies in psycho-social study of the people from all walks of life. Being a member of fractured society she cannot stop herself from describing bloodshed and horror but her spiritual self always sees a ray of hope for 'the emergence of a new man' in 21 st century. Her depiction of characters starts with a shipwreck but most of the time they turn their lot of life by becoming salvagers. The closure of all the stories is striking, strange and shocking with the spell of pleasant or unpleasant surprise. The present paper deals prominently with two stories based on children prominently. She is a great humanist who initiates her characters to spiritual values such as the life furthering survival and positive acceptance of life in spite of adversities that marks the salvaging phase. Her stories portray the transition from the psychological state of the shipwreck to the stage of salvage through the attainment of calmness of mind. 'Once upon a Time' is a tragedy of a white family that loses their son due to their overprotective and possessive attitude towards life. They install most effective security system to their compound wall of their house of 'a continuous coil of stiff and shining metal serrated into jagged blades' (29) against the black intruders. It clearly brings out disturbed psyche of the parents due to insecure life in the country. The son, on the other hand romanticizes life of a prince and the compound wall to be a thicket of thorns from which he desires to rescue a princess. $\mathrm{He}$ ironically becomes the victim of the web of adult maneuvering. 'The Ultimate Safari' tells us the sad story of an eleven year old black refugee girl from Mozambique who moves to neighbouring country due to war for seeking a shelter. It is a touching story of a grandmother who tries her best to save her grandchildren that has been narrated in the point of view of a granddaughter. All the stories reveal human nature and psyche of the children of different age groups. The paper tries to prove that mind has tremendous power to go through the shipwreck and later on to reach the salvage.
\end{abstract}

Keywords South Africa, Shipwreck, Salvage, Discrimination, Race, Apartheid, Post-Apartheid

\section{Introduction}

The evolution of man from a savage to that of a salvager is due to his learning through experiences. He has evolved as a distinct species due to his use of rational self and conscience. It is his ideology that has divided the history of mankind into a clash between binary oppositions like the strong vs. the weak, and the center vs. the margin and the superior vs. the inferior. The history of South Africa is a tale of 'the policy of apartheid' that was designed to ensure white supremacy. The post-apartheid period has officially completed twenty years but in reality apartheid is still in practice in seemingly intractable challenges of poverty, social inequality, discrimination and tyranny. The period is carrying the burden of miserable memories of the past and a challenge of retrospection and introspection in the present. It poses us to look at the past, the present and the future with positive coping mechanism that leads the sufferers to come out of the apartheid psyche. Nadine Gordimer, a recipient of many prestigious literary awards and a Nobel laureate of South Africa is known as a humanist and a social reformer for her concern for the marginalized. Her Jump and Other Stories (1991) is a collection of sixteen stories that can be best described as a microcosm of the life in Africa. Being a humanist her prominent concern lies in psycho-social study of the people from all walks of life. She was born and brought up in a fractured society where constant threat of bloodshed and horror was a routine but her spiritual self always sees a ray of hope for 'the emergence of a new human being' in the 21 st century. The apartheid policy of South Africa has given a formal closure in 1994 with a message that 'might is not always right'. Her human concern reflects in her vision of a 'rainbow colour family' in every African home that would remove race forever from the minds of the people. The present paper attempts to show a journey of life of an African born from the shipwreck to the salvager. The characters from the collection are from different walks and flavours of life but with a common message of 'treat one another as humans'. The selected two stories deal with children's innocent psyche that is completely unaware of the adult strategic and manipulative world. The first selected story Once Upon a Time is a tragedy of a white boy that gives a message to all 
inhuman practices that 'what you sow so you reap'. The second story The Ultimate Safari is a tragic story of pangs and pains of a refugee girl from the marginalized black race that tells us 'where there is a will there is away'. In order to understand psychological stress of the circumstances on the minds of the innocent children in the selected stories during their formative years of personality development let us refer to some of the psychoanalyst theorists.

\section{Methodology}

The present paper follows descriptive and analytical method through which the researcher wants to apply psychoanalytical theory of personality development of children of five to twelve years age group. The selected two stories deal with the development of small children. The paper is a psycho-social study of the growing children portrayed in the selected short stories by Nadine Gordimer from South Africa. The terms highlighted in the title 'the Shipwreck' and 'the Salvage' explains a journey of a human being from a savage to a salvager.

Psychoanalysts like Freud, Erikson and many others have developed theories related to the development of one's personality. Freud's theory of psychoanalysis deals with the dynamics of personality that depend on development of id, ego and super ego during the formative years. The childhood stage plays very important role in the formation of different types of identities. Erikson has stated psychological theory of personality development in a series of stages through social interaction and an integrated sense of self. This development of the 'ego identity' keeps on changing throughout one's life due to exposure to the encounters in day today life. G. Stanley Hall, an American psychologist has coined a term 'storm and stress' during the adolescent phase of one's life. Margaret Mead in a cultural anthropological standpoint believes that culture specific identities play significant role in shaping of the personality. Though there are several challenges and hindrances in shaping of the personality, life can be made smooth through adaptive and constructive positive coping mechanisms. According to Lazarus, emotional intelligence and coping methods help an individual in becoming a salvager by self-soothing strategies from anxiety, irritability, gloom and distress. A child starts understanding individual differences, social and cultural variations that leads to his shaping of a personality. In order to fight the battle of life successfully with mental peace one needs to develop holistic approach to human existence introduced through humanistic theories. Humanistic approach towards life encourages us to be an ethical, a social, a sensitive and a sensible human being. The mindset of the children in the selected stories is analyzed on the basis of these theories. The significance of the title with the metaphors 'shipwreck' and 'salvage' need to discuss in the light of South African experience.

The term 'shipwreck' expresses mental agonies and 'ruin or wreckage' in the personality which spoils hope and expectations of the sufferer. The wreckage to the psyche is due to stigma of non-normal conditions at home and in the society. Being a colonial country South African literature expresses disturbed mind-set of the former colonial and the colonized. The individuals from different races, family background, educational and financial set up can imagine each-other's lot of life but can never feel the agonies of it. Especially speaking of South African mindset the gap between the center and the margin is so widened that it has become very hard to the natives to cope with injustices and subjugation on various reasons. They feel that their life is a 'ship' that is 'sinking' in the sea without knowing how to reach at the shore. Gordimer's My Son's Story (1990) reflects wreckage to the minds of the coloured family's suffocation due to alienation and isolation from the main stream of the city in which the protagonist Will utters the following words:

"...are the three of us survivors of his shipwreck, under his command to build a new shelter for some dream of family he wants to come back to?" (Gordimer1990:251)

The term 'shipwreck' is repeatedly used in the novels of $\mathrm{V}$. S. Naipaul and J. M. Coetzee due to their colonial identity.

The salvage stage comes when one triumphs over the setbacks in one's life. A rational self of an individual tries to develop his own philosophy of life through experiences by becoming a salvager. A journey of an individual from shipwreak to salvage is a spiritual enlightenment that leads oneself to overcome pitfalls of one's life and conquer it like an emperor of his own life. The journey of life that starts with various kinds of complexes, but with a strong mind-set and positive attitude towards life, leads to ultimate reward at the autumn of one's life. Gautam Buddha, Samrat Ashoka, Mahatma Gandhi, Martin Luther King Jr., Nelson Mandela, and many others from classes to masses have faced challenges of life and proceeded further from a doom's day to the day of enlightenment. The former colonizer and the colonized are coping with dilemma of placelessness and rootlessness, an exile to that of home coming, from alienation and isolation to homogenization with distinct varieties of the societies, and from the native land and the land of the colonizer. A journey from several setbacks to partial stability has possible due to unsurpassable will power and sense of maturity of the countrymen. The apartheid conditions and disturbed state of mind is very well reflected in the following selected story.

Once Upon A Time is a heart rendering and touching story that reveals tragic consequences due to strenuous relationship between the whites and the blacks during apartheid. The story is told in the style of folklore without giving proper names to the characters due to which it appears to be an every man's story from South Africa. The story starts with a feeling of a happy and contented white family that includes a husband, a wife, a son and a grandmother nicknamed as 'that wise old witch' and a trustworthy black housemaid and itinerant gardener along with pets- a cat and a 
dog as playmates of the boy. The family lives with materialistic comforts like 'a car and caravan trailer for holidays, and a swimming-pool which was fenced so that the little boy and his playmates would not fall in the drown'. The contentment of the family is often described by the author as 'were living happily ever after'. The society where they are living 'inscribed in medical benefit with the licensed pet dog, the home insured against fire, flood damage and theft but not against the riots'. The gate of the house is lettered 'YOU HAVE BEEN WARNED' for a would-be intruder that is subscribed with the local neighbourhood watch which supplies with a plaque.

The author describes the disparity between the two races by mentioning the marginalized race as 'people of another colour' living outside the city as per the separate inhabitation law of apartheid. The husband tells his wife not to worry about the intruders as nobody is entertained except trusted maids and gardeners from 'that' race. He assures her that they are safe with 'the police and soldiers and tear-gas and guns'. To safeguard the family from 'buses burned, cars stoned, and school children shot by the police' he fits electronically controlled gates and the receiver that the son uses as his 'walkie-talkie'. The labourers of 'another colour' are deliberately allowed in the suburb for selfish purposes.

The black intruders are the main cause of worry except the black gardener and the maid for the family. The family comes to know about the burglary in which the trusted housemaid is tied up and shut in the cupboard by thieves when she is in charge of her employer's house. The family installs the burglar bars attached to doors and windows and an alarm system immediately on the demand of the maid. The family enjoys beautiful scenery of the nature "the trees and sky through bars' like a caged bird. The alarm system rings with the movements of the pets and it becomes nuisance to the family. The family strictly follows the old witch's advice of not 'taking on anyone off the street.' The wife gives food to the hungry intruders but the maid opposes it on the reason that they are loafers. The family raises height of the compound wall so that no one would come inside. The old witch pays the bill as her Christmas present. She gives a gift to her grandson of 'Space Man outfit' and a book of 'fairy tales'. The life goes on with the dinner parties with a certain couple at night along with robbery cases discussion that confirms a fussy life of the elite class.

The man, the wife, the little boy and the dog go for walk to the neighbouring street where they come across a house with the aesthetics of prison architecture with the Spanish Villa style that they decide to installa security system of 'a continuous coil of stiff and shining metal serrated into jagged blades' to their wall. The aim behind it is that the one who dares to go near it will be getting 'bloodier and bloodier, a deeper and sharper hooking and tearing of flesh'. The board is fixed to the wall that asks 'consult DRAGON'S TEETHthe People for Total Security'. The wife is worried about the cat's safety on which the husband says that the cat always looks before he leaps. One day the mother reads the fairy tale to the boy to sleep. The very next day the boy pretends:
' $\ldots$ to be the prince who braves the terrible thickets of thorns to enter the palace and kiss the Sleeping Beauty back to life; he dragged a ladder to the wall, the shining coiled tunnel was just wide enough for his little body to creep in, and with the first fixing of its razor-teeth in his knees and hands and head he screamed and struggled deeper into tangle.'(30)

The maid and the gardener along with his parents try to save him but they could see the bleeding mass.

The story ends with the tragic death of an innocent boy in the manmade trap. The nature's law proves supreme and man's law gets defeated like 'man proposes and God disposes'. The boy is completely out of everybody's mind, gets caught in the net woven by his own parents for his own security. The fairy tales' book gifted by the old witch for entertainment purpose becomes life stealer. Her over-sensitivity for her grand child leads her to take insensible decision and proves her real witch who indirectly devours his life. The device installed for security purposes of the owners endangers the life of the installer. Though the center has tried to keep the margin at space the same can be seen from the point of view of the divine power that has kept the so called superior race at space. W. B. Yeats in his poem The Second Coming states that 'the center cannot hold' that proves appropriate to the situation.

The couple can be looked upon as salvagers because they have realized the death as permanent loss of life no matter whether it is an intruder or their own child. Thus the story ends with the message 'what you sow so you reap'. The pit that you dig for others may take you as well. The author portrays the Nature or the God as the supremeintruder whom no security device can stop. The author has maintained irony throughout the story with the phrase 'were living happily ever after'. Actually the life in the destabilized society is 'never ever happy' due to the constant threat of horror and blood shade. The shipwrecked mind-set of the white family reaches to the salvage stage through enlightenment of 'survival rather than death stands above all' after losing their only child in their own trap. The story ends with the message for both the races that 'violence leads to violence'. Peace of mind along with equality, fraternity and brotherhood can be the only solution for all inequalities, injustices and evils on the earth. Nadine Gordimer when interviewed by Johanns Riis expressed her true feelings against the whites' imposition. She at her twenty went to perform a play in a black township and in front of the black audience. She found the description which she had portrayed in the story was a perfect location of the black township. She openly blamed her race for their discrimination:

"I had never been in a black township before, it was filthy, ghastly, all of the story's descriptions of the environment are absolutely true to what I saw. I think I suffered a sort of culture shock in my native country: what I saw was so vastly different from the white world I knew, and yet so close in distance a few miles from where I lived. And who were we, feeling superior, 
showing off European culture in this South African drop, to an audience with no background for understanding what we were doing, an audience whose own culture we did not know at all?" (Riis 1980:22)

The Ultimate Safari, the second selected story can be best described as a travelogue that explores the 'journey for survival' through a nine year old child-narrator girl. It is a story of a black family about the aftermaths of the prolonged war in Mozambique. The story is narrated in the first person by a nine year old small girl from a village from Mozambique. The family before the war consists of parents and the elder son, the middle girl and the younger son. The father dies in the fight with the terrorists whom the narrator calls the bandits. The mother is missing during the attack of bandits. The village has become a ruined place without having signs of normal life with school, church etc. The girl describes monotony of life as people in the village have to struggle hard for their daily bread and butter rather than remembering the days of week like Mondays and Sundays. The children become orphans but the grandmother and the grandfather come to their help. The story ends with a positive note that the stagnated and meaningless existence of the natives slowly come in the flow with a new beginning in altogether new refugee identity.

In the beginning of the story the girl tells us that her mother and father go out of the house and do not return. It is told in such coldness that it shows that it has become a routine for all the people from Mozambique. The war, the girl is talking about, has started between the terrorists and the government. She describes the life under terror of the bandits who chase the innocent people, 'like chickens chased by dogs'. The family is living in dire poverty without proper food and shelter. It so happens with the mother that she goes to get some oil for cooking that is supposed to be distributed in charity. At one end children start visualizing sumptuous food for the day that they have not tasted for a long time and at the other end the mother becomes the victim of terrorists. She tells that the bandits attack the village twice and looted everything and third time there is nothing to take away "no oil, no food'. They burned the thatch and roof of the house fell down. The house is made again by children with 'some pieces of tin'. Third time the children face the bandits hiding themselves under the tin house without roof. The elder one holds a piece of wood in his hand to hit the bandits. The younger one clings to his sister like 'a baby monkey to its mother'.

The girl tells us that their grandmother who is stronger than the grandfather comes to their rescue. She takes them to her home under the constant threat of the attack of the bandits on the way. They are without proper food for a month. The younger one being a baby gets milk from the breast from of an unknown woman. Since nothing is left to eat all the villagers have eaten up the leaves of spinach. The grandfather's three sheep, a cow and a vegetable garden have been destroyed by the bandits and they have no seeds to plant. The children want to go away to the safer place where they will be completely free from the fear of bandits and with the signs and memories of their mother. They want plenty of food. The villagers decide to take shelter in the neighbouring country. The grandmother exchanges her church clothes for dried mealies that can feed themselves during the journey and sells her shoes for the sake of water container that is very much needed on the way. The girl sees that the church visit has become secondary and children's safety has become priority for the grandmother.

The way to the chosen place goes from Kruger Park. The journey begins without the fear of bandits but under the danger of the attack of wild animals. Many people from the villages on their root join them. The girl says that they are shifting from the man-made world to the kingdom of animals. She observes that the blacks are the security guards in the park and the whites enjoy wild life in their protection. Since the folk is moving illegally they take care of not to get caught in the security check. The girl with the mixed feelings of thrill, excitement and fear remembers some incidents in which villagers had lost their body parts in the attack of the wild.

The park is fenced with electric current for safety reasons whereas the light the girl has seen 'on poles that give electric light in our towns'. The leader of the troop informs them that they will not light fire otherwise the police would catch them easily and send them back to their places. They happen to come across a big crowd of elephants that thrills the children but the leader asks them to stand still. The girl complains that the animals don't leave food for them as they eat all the time. They are moving ahead by day and night. The grandmother carries the younger one on her back. The girl says that her younger brother is becoming thin but heavy at the same time and the elder one is so tired that he stops talking. She notices that the flies are crawling on the grandmother's face that she doesn't try to remove as she is exhausted. The girl describes that the whites cook meat in the camps that used to tempt the hungry mob. The paradox of the situation is very well brought out by the author that the one end is striving for basic rights and the other end is enjoying all luxuries of life.

The folk come across the guards of their race working in the park. One of the women decides ask them for the waste food lies in the dustbins. The leader warns them not to do so otherwise their people will lose jobs. The guards though notice their presence pretends not to see anything. The most awaiting moment for the children is to see the lion. The girl shuts her eyes and preys that the lion should spare her. The leader starts beating the tree with a dead branch and starts shouting. The lions go away. The grandmother's feet start bleeding while crossing the river. The conflict between carrying the baskets and carrying one's own heavy and inactive body resolves with the decision that the body with the soul is of supreme importance. The women with the babies on their back proceed further.

The grandfather cannot match with the speed of the others. Moving from the elephant grass the insects start singing in the ears and biting. The grandfather cannot cope with the 
ghastly situation and gets lost in the tall grass. The search goes on throughout the night but he is not found. The girl sees the vultures start moving on their heads. The grandmother without uttering a single word determines to move without the grandfather. She looks at the three grand children and decides to move on for them. The girl describes,

'...she swung my little brother onto her back, tied him in her cloth- the top of her dress was torn and her big breasts were showing but there was nothing in them for him. She said, Come'. (41)

At last the folk reach in the area where many people have taken shelter. The girl, without knowing word 'refugee' starts describing her life in a tent. She remembers that she has seen those tents when she accompanies her mother in search of her father in the tents under police observation. She comes to know from the nurse that there are nearly two hundred adults coming from the villages from the neighbouring country. She describes the tent as mountain-shaped inside which we live. She and her elder brother take treatment in the clinic for better health that has lost due to starvation. She suffers from hallucination, 'I was walking, the grass was long, I saw the elephants, I didn't know we were away'. Her younger brother doesn't play as he has some problem in his head but is under medication. He remains with the grandmother and watches them all the time. She hopes that her brother will be alright one day with the help of the medicines. The grandmother according to the girl is strong who once again starts life with a hope of better future for her grand children. The life crawls slowly with the punching cards to get milk, food, clothes and medicines and old clothes from the church. The children have enough food to eat and clothes to wear.

The girl surprises when she sees the people in the new nation speak their language. The Kruger Park earlier belonged to a nation that has got divided then into two. The girl turns into eleven and the younger one is three years old. Soon the tent turns into a home with a garden with a fence where they plant beans, mealies and cabbage and a calendar too. The grandmother works in the city as a labourer on the construction from where she brings waste papers forcovering school books. She makes the kids to do their home work before it gets dark. She buys sugar, tea, milk and soap. She doesn't buy a pair of shoes for herself but buys school shoes for her and her elder brother and trains them in keeping it clean. She says, 'No other children in the tent have real shoes. When we three look at them it's as if we are in a real house again, with no war, no away'.

The white people come to make a documentary on their lives. The grandmother tells the lady that they are living in the tent for two years and a month. She has no dreams for herself but at the same time she wants her grand children should become educated and get jobs. The white woman asks her that whether she wants to go back to her country. She denies as there is no home left, she says. The girl doesn't like the answer because she thinks that after the war there would be her mother waiting for her and her grandfather would be on his way to home. She is hopeful about the gathering of the family members without knowing the reality.

During the crucial formative years of formation of identity that helps to develop one's personality the children in the stories try to cope up with the outside forces that don't allow them to be like a prince in the Arabian Knights or to be safe and happy with the parents forgetting bandits and huge animals from the Kruger Park. The home stands for harmony but both the stories reveal it without domestic harmony due to manmade tensions of segregation. In the first story the parents are over-protective and the child is naïve whereas, in the second story the parents are missing and the children try to cope up with the circumstances. The son in the first story is living like a king in the fort whereas; the girl in the second story is in search of home. The parents in the first story lose everything except comforts and luxuries but on the other hand the grandmother in the second story is victorious s she survives her grandchildren in extreme conditions. The socio-cultural disparity between both the families is so extensive that can never lead to take one another's place in near future. The parents instead of concentrating on their parenting they are worried about their survival. The woman that feeds the younger son without bothering about his religion and race proves her civilized in real sense of terms. The efforts of the neighbouring country in providing shelter are a step towards egalitarian approach. Forgetting the issues and focusing on the welfare can be taken as a step towards salvage. Neither the colonizer nor the colonized are taking complete breathe in the polluted atmosphere. Humanistic theorists have tried to find out the answer to social-political and cultural diversities. Franz Fanon has explained true liberation of mankind as:

"That imperialism which today is fighting against a true liberation of mankind leaves in its wake here and there tinctures of decay which we must search out and mercilessly expel from our land and our spirits". (Fanon 1963:200)

The grandmother is the salvager in true sense who understands that all materialistic things are immaterial but survival of her kids is above all assets. She takes her husband's death as a biological end of every life that no one can avoid. Her life philosophy is to live for the welfare of all. The children are also salvagers who adapt coping mechanisms and learn to survive. The shipwreck mindset of the colonizer had proceeded towards salvage stage when they decided to offer complete freedom. The freedom in real sense of terms is yet to be achieved that will bring peace and contentedness. The age old dictum of the notion of superiority and inferiority will take some time to come out of the minds but the process has begun. The one who overcomes all obstacles and reaches to the destination can be called the salvager. Liliane Louvel in her article Nadine Gordimer's My Son's Story: or the Experience of Fragmentation', tries to highlight Gordimer's hope of her Utopian South African society:

"The result of such schizophrenic society is a divided 
self, yet Gordimer notices the first signs of hope leading to a post-apartheid society. As the story proceeds, she refers to the fact that lovers of different races can go to a hotel together without being sent away, that beaches are desegregated, that libraries are virtually open to all. Increased opportunities are offered to coloureds and blacks, university degrees in particular. Some of them can even make money. Yet she also points out to the fact that although by law resettlement zones or 'grey zones' are offered to mixed population, the Group Areas Act remains very much alive in white people's minds as they cannot bear to part with it". (Louvel 1992:30)

\section{Results}

The children from the fiction and reality would turn into citizens of post-apartheid era very soon. They have to learn that the colour of brain is more appreciable than the colour of face. They must learn that 'simple living and high thinking' of ordinary men like Nelson Mandela have created the history. Elders have to be very conscious about their responsible behavior that alone can speak volumes of 'dos and don'ts', for the coming generations. The basic principles of 'give respect, get respect', and 'forget and forgive' have to nurture carefully. The children must respect one-another's cultural, political, economic, civil and social rights for local and global mutual interaction and coordination. They have to accept the challenges of globalization, discrimination, segregation and exploitation across the world. They would realize very soon that neo-colonial challenge of replacing the old notions of power by the new ideology of the dominant and the dominated would again lead to violence and dissatisfaction. Above all they must not get attracted to the cold war for becoming economic and nuclear superpower among the nations. The nation has to take necessary steps in removing all evils so that the children will enjoy love, beauty, community and democracy on local and global level. Mahatma Gandhi, the father of the India has asked us to respect the god and triumph over the demon within us. The emergence of a new human being as a 'salvager' is associated with the idea of 'rainbow colour nation', 'homogenization of cultures', 'nurturing of good and irradiation of all evils' and 'solace of mind'.

To conclude, following poem can be addressed to all the children who want to come out of the restricted psyche:
Bird

Come, I'll hold you cupped in my two hands Stroke your smooth feathers

Open the bars of my fingers and let you Go!

Through the spaces of the iron bars Fly!

Come, lover, comrade, friend, child, bird Come

I entice you with my crumbs, see-Dove Spring of olive in its beak

Dashes in the swift through the bars, breaks its neck

Against stone walls. (Gordimer 1990:277)

\section{REFERENCES}

[1] Gordimer, Nadine. Jump and Other Stories.Great Britain: Bloomsbury, 1991.

[2] Gordimer, Nadine. A Sport of Nature. London: Jonathan Cape Ltd., 1987.

[3] Gordimer, Nadine. My Son's Story. Great Britain: Bloomsbury, 1990.

[4] Beier, Ulli. (ed) Introduction to African Literature: An Anthology of Critical Writing. London: Longman Group Ltd., 1967.

[5] Clingman, Stephen, (ed.) Nadine Gordimer: The Essential Gesture.New York, 1989.

[6] Cooke, John. Nadine Gordimer's World of Black and White: A Study of her Political Novels and stories, BotonRauge: Louisiana State University press, 1985

[7] Dubbeld, Catherine E. "Reflecting Apartheid: South African Short Stories in English with Socio- Political Themes". 1960-1987, Research in African Literature, Vol. 23, No. 3 (Fall 1992): 142-44.

[8] Fanon, Frantz. The Wretched of the Earth, trans. Constance Farrington, Harmondsworth: Penguin, 1963.

[9] Harlow, Barbra. "Reading Nadine Gordimer".Research in African Literatures.Vol. 26, No 4 (Winter-1995):235-38.

[10] Haugh, Robert F. Nadine Gordimer. New York: Twayne Publishers, 1974.

[11] Head, Dominic. NADINE GORDIMER. Cambridge Studies in African and Caribbean Literature, Cambridge University Press, London: University of Cambridge, 1994.

[12] Louvel, Lilian. "Nadine Gordimer's "My Son's Story" or the Experience of Fragmentation". Commonwealth Essays and Studies, Vol. 14, No. 2. (Spring 1992): 28-33.

[13] Riis, Johannes. "Interview: Nadine Gordimer". Kunapipi, Vol. 2, no. 1 (1980):20-26. 